\title{
The Association of Self-Assessed Emotional Intelligence with Academic Achievement and General Health among Students of Medical Sciences
}

\author{
Enam Alhagh Charkhat Gorgich ${ }^{1}$, Sanam Barfroshan ${ }^{1}$, Gholamreza Ghoreishi ${ }^{1}$, Abbas Balouchi ${ }^{2}$, \\ Naser Nastizaie $^{3}$ \& Azizollah Arbabisarjou ${ }^{4}$ \\ ${ }^{1}$ Student Scientific Research Center, Zahedan University of Medical Sciences, Zahedan, Iran \\ ${ }^{2}$ Department of Medical and Surgical Nursing, Zabol University of Medical Sciences, Zabol, Iran \\ ${ }^{3}$ Faculty of Educational Sciences and Psychology, University of Sistan and Baluchestan, Zahedan, Iran \\ ${ }^{4}$ Health Promotion Research Center, Zahedan University of Medical Sciences, Zahedan, Iran \\ Correspondence: Azizollah Arbabisarjou, Health Promotion Research Center, Zahedan University of Medical \\ Sciences, Zahedan, Iran. E-mail: arbabisarjou2007@gmail.com
}

Received: December 18, 2016 Accepted: March 27, 2016 Online Published: April 29, 2016

doi:10.5539/gjhs.v8n12p27 URL: http://dx.doi.org/10.5539/gjhs.v8n12p27

\begin{abstract}
Introduction and Aim: Emotional intelligence is one of the most important leading factors influencing different aspects of human life. It leads individuals to percept their feelings for appropriate decision making and fields for future accomplishments. The aim of this study was to Investigation of the associations of self-assessed EI with academic achievement and general health among medical students.
\end{abstract}

Materials \& Methods: This cross-sectional study was conducted on 426 students of Zahedan University of Medical Sciences from October 2014 to May 2015. Random sampling method was used. Sibria Shring standard emotional intelligence questionnaire and Goldberg's standard general health questionnaire (GHQ-28) were used for data collecting. Data analysis was through descriptive statistics (mean, standard deviation) and inferential statistics (t-test, ANOVA and Pearson correlation coefficient) by SPSS v.21. The tests significant level was considered 0.05 .

Findings: The average total score of emotional intelligence in males $(102.23 \pm 1.67)$ was better in comparison with females (98.54 \pm 2.23$)$. There was not any significant difference in total mean scores of students of different fields of Study $(\mathrm{P}=0.211)$. According to ANOVA test, it has not observed any significant difference between scores of emotional intelligence scales of students from different domains of study. The results of Pearson correlation test confirmed a positive significant correlation between emotional intelligence, academic achievement and general health.

Conclusion: According to the results of this study that has shown a significant relationship between emotional intelligence, general health and academic achievement, it is needed to hold some workshops and classes for emotional intelligence improvement.

Keywords: emotional intelligence, general health, academic achievement, students of medical sciences

\section{Introduction}

Emotional Intelligence (EI) is an aspect of human intelligence. It was raised for first time in 1990 and after that many psychologists and researchers were interested in it (Akerjordet \& Severinsson, 2010; Goleman, 1996; Santrock, Woloshyn, Gallagher, Petta, et al., 2007). Bar-On defines EI as abilities and skills that prepare an individual for effective interactions with the community and to be successful in life (Bar-On, 2010). Most researchers believe that emotional conciseness and emotional management are key factors of EI (Batt-Rawden, Chisolm, Anton, \& Flickinger, 2013; Chew, Zain, \& Hassan, 2013). Lack of awareness causes lack of confidence and development. In other words EI is a combination of emotions and intelligences. Using emotions as a protector of our decisions can help us having a better life. It is good to know that the studies had shown that more of life achievements depends on individual EI (Akbari, Rezaeian, \& Moudi, 2007; Brackett, Rivers, \& 
Salovey, 2011). According to these studies EI is one of the factors that effects on academic, occupational and social interaction achievements. Today, it is ruled out that EI education to people can effect on their academic achievement (AA) (Chew, Md. Zain, \& Hassan, 2015), general health(GH) (Sarah et al., 2014), occupational achievement (Joseph, Jin, Newman, \& O'Boyle, 2014), family relationships(Malouff, Schutte, \& Thorsteinsson, 2014), teens aggression reduction (Tamannaifar, Arfai, \& Mohammadabadi, 2010), youth happiness increase, better decision makings (Stratton, Saunders, \& Elam, 2008), internet addiction reduction, intrapersonal interaction's reinforcement, stress reduction and job satisfaction increase (Akerjordet \& Severinsson, 2010; Joseph et al., 2014).

About the relation between EI and AA some studies were conducted. The results of three studies did not show any significant relationship between EI and AA (Chinipardaz, Boroujerdni, Pasalar, \& Keshavarz, 2012; Stratton et al., 2008; Tamannaifar et al., 2010). But the results of other studies have confirmed a meaningfull association among EI and AA (Austin, Evans, Goldwater, \& Potter, 2005; Bakhshi Surshejani, 2008; Parker, Summerfeldt, Hogan, \& Majeski, 2004; Rostami et al., 2010). Students are as educated human resources in every society and they will handle the future of the country. So then their health is important for the country and the officials should try hard for this aim (Enaam-Al-Hagh, Maryam, Salehinia, Ali, \& Masoud, 2014; Gorgich, Barfroshan, Ghoreishi, \& Yaghoobi, 2015). This trying can be through preventing programs and reinforcement of educational activities (Taylor \& Sirois, 1995).

Educational, cultural, social and economic problems can cause stress for any one. Medical students have their own problems separate of the problems above such as psychological problems in hospitals facing the patients and their problems such as incurable disease and their death and also facing mourner families (Jahani, Rahimzadeh, Ghafelehbashi, \& Sarichlou, 2008). GH and having large capacity for facing the mental stress are necessary for academic and after that occupational achievement for medical students. Today, the relationship between GH and cognitive and psychological factors are considered and examined. EI is considered in intrapersonal relations and it is closely related to physical and mental health (Boussiakou, Boussiakou, \& Kalkani, 2006 (Cherry, Fletcher, O’Sullivan, \& Dornan, 2014). Studies had shown that individuals who have higher EI have higher mental and physical health (Ashkanasy \& Dasborough, 2003; Palmer, Gardner, \& Stough, 2003). Educational activities specially teaching necessary skills for having a good life can improve student's health. One of these educational activities is emotional intelligence which is emphasized by researchers and psychologists. EI gives this ability to the person to identify and evaluate emotions in a correct way. It gives a good awareness of human environment and lets you to identify your own and others emotions properly. And it gives an ability to use emotional knowledge to guide the cognitive activities for adaptive actions (Mayer, Salovey, \& Caruso, 2000). Studies had shown the direct relation between EI and AA (Surshejani, 2008; Boussiakou et al., 2006; E, 1995).

EI is important. It affects different parts of our lives such as AA and GH. Medical students are directly in interaction with society health so then they should be healthy otherwise they can't provide health to the society. So then this study aimed to to Investigation of the associations of self-assessed EI with academic achievement and general health among medical student's students.

\section{Reviews of Literatures}

Evidence suggests that the EI is effective as a predictor factors of academic performance in student's cognitive functions (Qualter, Gardner, Pope, Hutchinson, \& Whiteley, 2012). In another study EI cause improving levels of academic achievement and student performance and it mentioned as a predictor factor for academic achievement (Codier \& Odell, 2014). However, in several researches by using different models around the world in at least one case reported conflicting results (Brannick, Wahi, \& Goldin, 2011; Duygulu, Hicdurmaz, \& Akyar, 2011). Although, in another study to examine the relationship between EI and academic achievements in 150 students, the researchers have found that EI is a cause of enhancing the academic achievement of students who were studying plans, and believed that EI is trainable and learn (Jaeger, Bresciani, \& Sabourin, 2003). In Lolaty's study that survey of EI and related factors in medical sciences' students showed that EI is effecting on the academic skills and there was significant relationship with an interest in the string (Lolaty, Tirgari, \& Fard, 2014). In a research titled effect of EI on geneeral health of students, the results demonsterated that there was a positive significant correlation between EI and students' general health and EI has considered as a powerful predictor for general health (Farrahi, Kafi, Karimi, \& Delazar, 2015).

Documents and evidentes suggested that EI has been improved general health aspects psychologically through regulation and modification of health (Fata, Moutabi, Shakiba, \& Barouti, 2008; Williams, Daley, Burnside, \& Hammond-Rowley, 2010). 


\section{Materials and Methods}

This cross-sectional study was conducted on 426 students of Zahedan University of Medical Sciences, in southeast Iran, Zahedan, from October 2014 to May 2015. Our population included all the students (3727, including 2351 females and 1376 males) studying in Zahedan University of Medical Sciences in 2014-2015 semester. The sample volume was 426 students chosen by stratified random sampling method. These subjects were chosen from those students who came to the computer site and the library of the university during the research. The reason which computer site and library were chosen was to maintain random sampling method of subjects about field of study, gender and age. Inclusion criteria were passing at least two academic terms at university. The students not included lower than second term and medical students in training and intrrnship course because they had not GPA for determining of academic achievement.

Informed consent was obtained through completing the questionnaire. Data collected was through standard questionnaire. This questionnaire consisted of three parts:

First part included demographic information (age, gender, field of study, etc.).

Second part was for investigation of EI. The Persian version of Sibria Shring EI questionnaire was used (Eskandarpour \& Amiri, 2012; Fathy, Mokhtari, \& Abadi, 2015). The original version EI questionnaire has 70 questions in two parts. In the first part each question is about a situation in life. The student choses the option which is more likely to his mood. In the second part, at beginning of every question there is an emotional story. Respondent should answer the question according to the story. These stories were did not have compliance with Iranian culture so they were removed from the questionnaire. The Iranian version EI questionnaire included 33 items (Eskandarpour \& Amiri, 2012; Fathy, Mokhtari, \& Abadi, 2015). All the items were based on a 5-point Likert scale form strongly disagree (score 1) to completely agree (score 5) in five aspects: self-consciences (8 items), Self-motivation (7 items), self-control (7 items), social awareness or empathy (5 items) and social skills (6 items). Min and max total score of questionnaire was in range 33-165. This questionnaire was used in so some research in Iran and its reliability has been approved (Mansouri, 2001; Miri et al., 2007; Molaie, Asayesh, Taghvakish, \& Ghorbani, 2012). In this study, researchers used The Cronbach's alpha for determining reliability and it calculated 0.91 for EI questionnaire.

In third part standard Goldberg's general health questionnaire(GHQ-28) (Goldberg, 1978) was used to investigate the GH (Jackson, 2007; Sakakibara, Miller, Orenczuk, \& Wolfe, 2009). Social dysfunction (7 items), anxiety/insomnia (7 items), severe depression7 items) and physical-mental (7 items) health disorders are 4 subscales of this questionnaire. Minimum and maximum score of each question is 0-3 and min and max total score of questionnaire was in range 0-84. The higher score in this questionnaire showed lower GH and lower score on it showed higher GH. The reliability was approved in many studies in Iran (Haqiqi, 1999; Taghavi, 2002). The reliability was calculated by Cronbach's alpha (0.89). Students GPA as criterion a measure of academic achievement was considered.

\section{Ethical Consideration}

The research requires an ethical declaration for the the research as human subjects are particiapted and has been approved by the Committee of Medical Ethics.Students were provided with an explanation to acquire their consent before filling out the questionnaire. At first, the aim of the research was mentioned for the subjects. After expalanation, the subjects were free to accept or avoid the invitation to be participated in the research. A written consent was not obtained because the time was limited and verbal consent was deemed as adequate. Then the questionnaires were given to them in nine steps in central library and central computer site.

\section{Statistical Analysis}

Statistical analysis was performed using IBM SPSS Statistic v21 (Chicago, IL). Data analysis was conducted through descriptive statistics (mean, standard deviation) and inferential statistics (t-test, ANOVA, Pearson correlation coefficient). The tests significant level was considered 0.05 .

\section{Findings}

The participants included 225 male and 201 female students. The age mean was $21.12 \pm 1.38$. The samples subjects were from school of medicine (60), school of allied health (143), school of health (112), school of nursing and midwifery (54) and school of rehabilitation school (57). Mean of total average GPA students was $16.30 \pm 1.53(16.37 \pm 1.92$ for males and $16.23 \pm 1.15$ for females). According to t-test, there was not any significant difference between these two groups ( $\mathrm{p}=0.341$ ). Mean of total EI score was $79.28 \pm 1.95$. Mean of total EI score was $102.23 \pm 1.67$ among male students while it was $98.54 \pm 2.23$ among female students. According to the t-test, there was a significant relationship between means of these two groups $(\mathrm{p}=0.003)$. Male students had a higher EI. 
According to the results shown in Table 1, there was no significant difference between mean of EI score and field of study ( $\mathrm{p}=0.211)$. According to the ANOVA test, there was not any significant difference between subscale scores of EI and student's field of study. Also the mean score of EI among students of medicine was $120.27 \pm 3.97$ which is more than other fields of study but it has not observed any significant difference between EI with field of study and age $(p=0.07)$. The Pearson correlation had shown a significant relationship between mean score of EI and mean of total average GPA $(\mathrm{p}=0.001, \mathrm{r}=0.53)$.

Table 1. Mean distribution and standard deviation of emotional intelligence in each of its aspects among students of medical sciences

\begin{tabular}{llllllll}
\hline Aspects of EI & $\begin{array}{l}\text { School of } \\
\text { Medicine }\end{array}$ & $\begin{array}{l}\text { School of } \\
\text { Allied } \\
\text { health }\end{array}$ & $\begin{array}{l}\text { School of } \\
\text { Health }\end{array}$ & $\begin{array}{l}\text { School of } \\
\text { Nursing \& } \\
\text { midwifery }\end{array}$ & $\begin{array}{l}\text { School of } \\
\text { Rehabilitation }\end{array}$ & F & p-values \\
\hline Self-consciousness & $24.28 \pm 3.63$ & $23.02 \pm 1.71$ & $22.35 \pm 2.52$ & $22.12 \pm 1.31$ & $21.61 \pm 1.05$ & 1.327 & 0.064 \\
Self-motivation & $20.23 \pm 4.45$ & $19.75 \pm 3.16$ & $19.41 \pm 2.44$ & $18.78 \pm 1.01$ & $19.01 \pm 4.12$ & 0.627 & 0.527 \\
Self-control & $21.35 \pm 6.12$ & $20.07 \pm 5.16$ & $19.24 \pm 3.87$ & $19.13 \pm 3.54$ & $18.07 \pm 1.14$ & 1.273 & 0.225 \\
Social awareness & $17.83 \pm 4.31$ & $17.35 \pm 3.90$ & $16.44 \pm 3.72$ & $15.90 \pm 2.96$ & $15.11 \pm 4.81$ & 0.854 & 0.198 \\
Social skills & $15.23 \pm 2.24$ & $15.12 \pm 4.63$ & $16.08 \pm 2.41$ & $16.24 \pm 5.02$ & $14.00 \pm 1.87$ & 1.432 & 0.412 \\
Total scores & $120.27 \pm 3.97$ & $95.34 \pm 2.54$ & $93.52 \pm 6.14$ & $92.17 \pm 1.17$ & $87.80 \pm 4.23$ & 0.348 & 0.211 \\
\hline
\end{tabular}

According to the t-test, there was significant difference in investigating the $\mathrm{GH}$ among males and females $(\mathrm{p}=0.023)$. However, according to Goldberg's General Health Questionnaire lower scores indicate higher general health. According to the result shown in Table 2 male subjects had a higher GH in comparison with females.

Table 2. Mean distribution and standard deviation of general health among male and female medical sciences students

\begin{tabular}{lllll}
\hline Group & Number & Mean and standard deviation & Maximum score & Minimum score \\
\hline Males & 225 & $59.33 \pm 2.86$ & 82 & 18 \\
Females & 201 & $76.14 \pm 4.81$ & 76 & 12 \\
\hline
\end{tabular}

The Pearson correlation had shown a positive significant correlation between EI, AA and GH. (Table 3)

Table 3. Pearson correlation coefficient between EI, AA and GH among medical sciences students

\begin{tabular}{lll}
\hline Variable & EI & p-values \\
\hline AA & 0.53 & 0.001 \\
GH & 0.47 & 0.001 \\
\hline
\end{tabular}

\section{Discussion}

This study aimed to survey the relationship among EI, AA and GH among medical sciences students of the mean of total emotional intelligence score was $97.28 \pm 1.95$. EI was significantly higher among male subjects. There was not any relation between EI and different fields of study. There was significant relation among EI and mean total average GPA of students that sowed the relationship between EI and AA. But there was not any significant diversity among each of EI subscales and different fields of study. The mean of student's EI score was lower in Salehi et.al. Study (Molaie et al., 2012; Salehi, Afghari, \& Moghadasi, 2012). But it was higher in Fakhri's study. Difference in EI score in different studies can be cause of different tools used in studies, different leveling of EI, difference of EI in students with different fields of study and also different cultures. This study had shown that mean of emotional intelligence in males is significantly more than females and there is a significant difference between them. The results of some studies are consistent with this study results (Gujjar, Naoreen, Aslam, \& Khattak, 2010; Mehdi, Azizi, \& Jamshidzadeh, 2011). Despite this alignment results, there are studies such as Stratton, Austin, Banihashemian, Bakhshisour, Shajani and Malaei's study that have shown a higher EI among 
females (Austin et al., 2005; Bakhshi Surshejani, 2008; Molaie et al., 2012; Stratton et al., 2008; Taghavi, 2002). There were not any significant differences among mean scores of male and female students in Noorbakhsh's study (Noorbakhsh, Besharat, \& Zarei, 2010). This conflict can be cause of cultural and social differences in societies and also ways of upbringing and cultural encounters among males and females. In some of these studeis they have pointed out the reason of lower EI among females is that they have limited access to social environments and other public societies in comparison with males. They explained that the difference of EI in males and females is cause of lower score in social intelligence subscale (Mehdizadeh et al., 2011). The results of this study had shown a positive meaningful relationship among EI and AA. But the results of some other studies such as Stratton, Parker, Chinipardaz, and Hajbagheri concluded that there was no relationship between these two EI and AA (Adib-Hajbaghery \& Lotfi, 2013; Chinipardaz et al., 2012; Parker et al., 2004; Stratton et al., 2008). But also there are studies consistent with present study about this such as Salehi's study titled AA and EI among nursing students and Song and Rode's study (Rode et al., 2008; Salehi et al., 2012; Song et al., 2010). The difference about this matter in different studies can be cause of effect of a group of factors and their cooperation. Different IQ's, family supports, individual, family society attitude and perspective toward education, good diet, educational system, types of education, types of evaluation and being interested in the field of the study are examples for these factors. Of course it should not neglected that EI is almost an acquired ability and it can be taught o others for having success in life and education (Gujjar et al., 2010; Stratton et al., 2008). Mayer and Salovey believed that EI can guarantee the success in life even more than IQ (Mayer, Salovey, \& Caruso, 2008). A higher EI gives this ability to the individual to understand and evaluate the educational concepts in a better way. Also he/she can organize his/her thoughts and memory contents about educational matters (Mousavi, Raeesi, \& Asgharnejade-Farid, 2012; Yaghoobi, Navidian, Charkhat-gorgich, \& Salehiniya, 2015). Based on the results of this study, total score of EI among medicine students was more than other fields of study but there was not whatsoever significant difference between mean of EI score and field of study. This was consistent with another study also (Adib-Hajbaghery \& Lotfi, 2013; Zahiroddin, Dibajnia, \& Gheidar, 2010). But Yavarian's study has demonstrated the relationship between EI and fields of study (Yavarian \& Ejaz, 2009; Libbrecht, Lievens, Carette, \& Côté, 2014). The results of present study had shown that male subjects had a higher mental health than females which is consistent with the results of some other studies such as Yaghoobi and Kurt (Marcotte, Alain, \& Gosselin, 1999). This difference can be cause of cultural climate that the females are facing with and limits that they have in the society, lack of freedom and also lack of vocational and sport facilities for them. The results of present study had shown a significant relation between EI and GH which is consistent with Salovey et al. study. This study had shown that high EI is associated with cortisol levels and lower blood pressure. This is really important for physical health (Salovey, Mayer, Goldman, Turvey, \& Palfai, 1995; (Hassan, Jani, Som, Hamid, \& Azizam, 2015). Also the results of this study are consistent with Ghorbani et al. and Farahbakhsh et al. results (Farahbakhsh, 2012; Ghorbani, Bing, Watson, Davison, \& Mack, 2002). Slaski and Schutte have shown in their investigation that emotional IE can decrease the stress and increases the flexibility of individuals. They said that if EI was increased the EI, it could be used as a technic to manage the stress (Schutte, Malouff, Thorsteinsson, Bhullar, \& Rooke, 2007; Slaski \& Cartwright, 2002). The data in this study were collected through self-report of students and they may not be completely true. But researchers tried their best to get the higher cooperation of students in this study. Given that this study was conducted on a special group of students it could not be used for all students and all academic diciplines.

\section{Conclusion}

This study was carried out to investigate the relationship between emotional intelligence, academic achievement and general health among medical sciences students. According to the results of present study there is a positive correlation between aspects of EI, GH and AA. Also EI is in relation with general health as an effective psychological factor. This is cause of this that there are some abilities in EI that make the individual able to process the emotional information easier and also they make the thoughts coherent. And finally it results in academic achievement and psychological and physical health. So then considering the EI and planning for it should start from childhood to get a good result in youths and university students. Pursuant to the results of this study that shows the punctual correlation among EI, GH and AA, it seems necessary to hold some classes and workshops about the EI development.

\section{Acknowledgements}

This article is the result of a student research project approved by Deputy of Research and Technology at Zahedan University of Medical Sciences. This study was approved by the Medical Ethics Committee of Zahedan University of Medical Sciences. All students participating in the present research who sincerely cooperated in obtaining the actual and real results are appreciated. 


\section{Competing Interests Statement}

The authors declare that there is no conflict of interests regarding the publication of this paper.

\section{References}

Adib-Hajbaghery, M., \& Lotfi, M. S. (2013). The Association of Emotional Intelligence with Academic Achievement and Characteristics of Students of Kashan University of Medical Sciences. Iranian Journal of Medical Education, 13(9), 703-710.

Akbari, M., Rezaeian, H., \& Moudi, M. (2007). Study of emotional intelligence of Arak University students and it's relation with computer anxiety, 129-134.

Akerjordet, K., \& Severinsson, E. (2010). The state of the science of emotional intelligence related to nursing leadership: An integrative review. Journal of Nursing Management, 18(4), 363-382. http://dx.doi.org/10. 1111/j.1365-2834.2010.01087.x

Ashkanasy, N. M., \& Dasborough, M. T. (2003). Emotional awareness and emotional intelligence in leadership teaching. Journal of Education for Business, 79(1), 18-22. http://dx.doi.org/10.1080/08832320309599082

Austin, E. J., Evans, P., Goldwater, R., \& Potter, V. (2005). A preliminary study of emotional intelligence, empathy and exam performance in first year medical students. Personality and Individual Differences, 39(8), 1395-1405. http://dx.doi.org/10.1016/j.paid.2005.04.014

Bar-On, R. (2010). Emotional intelligence: An integral part of positive psychology. South African Journal of Psychology, 40(1), 54-62. http://dx.doi.org/10.1177/008124631004000106

Batt-Rawden, S. A., Chisolm, M. S., Anton, B., \& Flickinger, T. E. (2013). Teaching empathy to medical students: An updated, systematic review. Academic Medicine, 88(8), 1171-1177. http://dx.doi.org/10.1097 /ACM.0b013e318299f3e3

Boussiakou, L. G., Boussiakou, I. K., \& Kalkani, E. C. (2006). Student development using emotional intelligence. World Transactions on Engineering and Technology Education, 5(1), 53.

Brackett, M. A., Rivers, S. E., \& Salovey, P. (2011). Emotional intelligence: Implications for personal, social, academic, and workplace success. Social and Personality Psychology Compass, 5(1), 88-103. http://dx.doi. org/10.1111/j.1751-9004.2010.00334.x

Brannick, M. T., Wahi, M. M., \& Goldin, S. B. (2011). Psychometrics of mayer-salovey-caruso emotional intelligence test (MSCEIT) scores 1. Psychological reports, 109(1), 327-337. http://dx.doi.org/10.2466/03. 04.PR0.109.4.327-337

Cherry, M. G., Fletcher, I., O’Sullivan, H., \& Dornan, T. (2014). Emotional intelligence in medical education: A critical review. Medical Education, 48(5), 468-478. http://dx.doi.org/10.1111/medu.12406

Chew, B.-H., Zain, A. M., \& Hassan, F. (2013). Emotional intelligence and academic performance in first and final year medical students: A cross-sectional study. BMC medical education, 13(1), 44. http://dx.doi.org/10. 1186/1472-6920-13-44

Chew, B.-H., Zain, A. M., \& Hassan, F. (2015). The relationship between the social management of emotional intelligence and academic performance among medical students. Psychology, Health \& Medicine, 20(2), 198-204. http://dx.doi.org/10.1080/13548506.2014.913797

Chinipardaz, Z., Boroujerdni, M. G., Pasalar, P., \& Keshavarz, A. (2012). Investigation of Emotional Intelligence and Its Relationship with Academic Achievement in Medical Students of Tehran University of Medical Sciences in 2008-2009. Journal of Strides Development Medical Education, 8(2), 167-172.

Codier, E., \& Odell, E. (2014). Measured emotional intelligence ability and grade point average in nursing students. Nurse Education Today, 34(4), 608-612. http://dx.doi.org/10.1016/j.nedt.2013.06.007

Duygulu, S., Hicdurmaz, D., \& Akyar, I. (2011). Nursing students' leadership and emotional intelligence in Turkey. Journal of Nursing Education, 50(5), 281-285. http://dx.doi.org/10.3928/01484834-20110130-07

Enaam-Al-Hagh, C.-G., Maryam, Y., Salehinia, H., Ali, N., \& Masoud, T. (2014). The types and causes of medication errors in nursing students. Science Road Journal, 2(8), 48-54.

Eskandarpour, B., \& Amiri, M. (2012). Survey of relationship between dimensions of emotional intelligence and effectiveness of managers' of Ardebil universities. International Research Journal of Applied and Basic Sciences, 3(7), 1369-1374. 
Farahbakhsh, S. (2012). The role of emotional intelligence in increasing quality of work life in school principals. Procedia-Social and Behavioral Sciences, 46, 31-35. http://dx.doi.org/10.1016/j.sbspro.2012.05.062

Farrahi, H., Kafi, S. M., Karimi, T., \& Delazar, R. (2015). Emotional Intelligence and Its Relationship With General Health Among the Students of University of Guilan, Iran. Iranian journal of psychiatry and behavioral sciences, 9(3). http://dx.doi.org/10.17795/ijpbs-1582

Fata, L., Moutabi, F., Shakiba, S., \& Barouti, E. (2008). Social-Emotional intelligence as predictor of general mental health.

Fathy, N., Mokhtari, R., \& Abadi, Z. Z. Y. (2015). Studying the Relationship between the Emotional Intelligence and the Employees' Job Stress. Jurnal UMP Social Sciences and Technology Management, 3(3).

Ghorbani, N., Bing, M. N., Watson, P. J., Davison, H. K., \& Mack, D. A. (2002). Self-reported emotional intelligence: Construct similarity and functional dissimilarity of higher-order processing in Iran and the United States. International Journal of Psychology, 37(5), 297-308. http://dx.doi.org/10.1080/00207590 244000098

Goldberg, D. (1978). Manual of the general health questionnaire. Nfer.

Goleman, D. (1996). Emotional Intelligence. Why It Can Matter More than IQ. Learning, 24(6), 49-50.

Gorgich, E. A. C., Barfroshan, S., Ghoreishi, G., \& Yaghoobi, M. (2015). Investigating the Causes of Medication Errors and Strategies to Prevention of Them from Nurses and Nursing Student Viewpoint. Global Journal of Health Science, 8(8), 220. http://dx.doi.org/10.5539/gjhs.v8n8p220

Gujjar, A. A., Naoreen, B., Aslam, S., \& Khattak, Z. I. (2010). Comparison of the emotional intelligence of the university students of the Punjab province. Procedia-Social and Behavioral Sciences, 2(2), 847-853. http://dx.doi.org/10.1016/j.sbspro.2010.03.114

Haqiqi, J. (1999). The relationship between tenacity and its elements with the mental health of post graduate male students at Shahid Chamran University of Ahvaz. Journal of Psychology and Education, 3(3\&4), 11-18.

Hassan, N., Jani, S. H. M., Som, R. M., Hamid, N. Z. A., \& Azizam, N. A. (2015). The Relationship between Emotional Intelligence and Teaching Effectiveness among Lecturers at Universiti Teknologi MARA, Puncak Alam, Malaysia. International Journal of Social Science and Humanity, 5(1), 1-5. http://dx.doi. org/10.7763/IJSSH.2015.V5.411

Jackson, C. (2007). The general health questionnaire. Occupational Medicine, 57(1), 79. http://dx.doi.org/10. 1093/occmed/kq1169

Jaeger, A., Bresciani, M., \& Sabourin, C. (2003). Predicting persistence and academic performance of first year students: An assessment of emotional intelligence and non-cognitive variables. Paper presented at the Association for the Study of Higher Education (ASHE) National Conference, Portland, OR.

Jahani, H. H., Rahimzade, M. S., Ghafelehbashi, H., \& Sarichlou, M. E. (2008). Investigating the mental health of the first-and last-year students of QUMS (2005).

Joseph, D. L., Jin, J., Newman, D. A., \& O’Boyle, E. H. (2014). Why does self-reported emotional intelligence predict job performance? A meta-analytic investigation of mixed EI.

Libbrecht, N., Lievens, F., Carette, B., \& Côté, S. (2014). Emotional intelligence predicts success in medical school. Emotion, 14(1), 64. http://dx.doi.org/10.1037/a0034392

Lolaty, H. A., Tirgari, A., \& Fard, J. H. (2014). Emotional intelligence and related factors in medical sciences students of an Iranian university. Iranian Journal of Nursing and Midwifery Research, 19(2), 203.

Malouff, J. M., Schutte, N. S., \& Thorsteinsson, E. B. (2014). Trait emotional intelligence and romantic relationship satisfaction: a meta-analysis. The American Journal of Family Therapy, 42(1), 53-66. http://dx.doi.org/10.1080/01926187.2012.748549

Mansouri, B. (2001). Normalization of Shrink Emotional Intelligence Questionnair at Tehran University. Tehran: Allameh University. Thesis of MA.

Marcotte, D., Alain, M., \& Gosselin, M.-J. (1999). Gender differences in adolescent depression: Gender-typed characteristics or problem-solving skills deficits? Sex Roles, 4l(1-2), 31-48. http://dx.doi.org/10.1023/A: 1018833607815

Mayer, J. D., Salovey, P., \& Caruso, D. R. (2000). Emotional intelligence as zeitgeist, as personality, and as a 
mental ability.

Mayer, J. D., Salovey, P., \& Caruso, D. R. (2008). Emotional intelligence: New ability or eclectic traits? American psychologist, 63(6), 503. http://dx.doi.org/10.1037/0003-066X.63.6.503

Mehdi, Z. H., Azizi, M., \& Jamshidzadeh, F. L. (2011). Investigation of Emotional Intelligence among Students of Medical Sciences Universities in Western Iran, 89-100.

Miri, M. R., et al. (2007). The correlation between emotional intelligence and school anxietyamong high school students in South Khorasan. Journal of Birjand University of Medical Sciences, 14(1), 54-59.

Molaie, E., Asayesh, H., Taghvakish, B., \& Ghorbani, M. (2012). Gender Difference and Emotional Intelligence in Golestan University of Medical Sciences' Students. Journal of Gorgan Bouyeh Faculty of Nursing \& Midwifery, 8(2), 30-34.

Mousavi, S. M., Raeesi, M., \& Asgharnejade-Farid, A. (2012). Study of Relationship between Emotional Intelligence and Educational Adjustment in Pre-University Girl Students of Tehran in 2008. Zahedan Journal of Research in Medical Sciences, 14(2), 91-95.

Noorbakhsh, S. N., Besharat, M. A., \& Zarei, J. (2010). Emotional intelligence and coping styles with stress. Procedia-Social and Behavioral Sciences, 5, 818-822. http://dx.doi.org/10.1016/j.sbspro.2010.07.191

Palmer, B, Gardner, L, \& Stough, C. (2003). The relationship between emotional intelligence, personality and effective leadership. Paper presented at the Australian Journal of Psychology.

Parker, J. D. A., Summerfeldt, L. J., Hogan, M. J., \& Majeski, S. A. (2004). Emotional intelligence and academic success: Examining the transition from high school to university. Personality and individual differences, 36(1), 163-172. http://dx.doi.org/10.1016/S0191-8869(03)00076-X

Qualter, P., Gardner, K. J., Pope, D. J., Hutchinson, J. M., \& Whiteley, H. E. (2012). Ability emotional intelligence, trait emotional intelligence, and academic success in British secondary schools: A 5year longitudinal study. Learning and Individual Differences, 22(1), 83-91. http://dx.doi.org/10.1016/j.lindif. 2011.11.007

Rode, J. C., Mooney, C. H., Arthaud-Day, M. L., Near, J. P., Rubin, R. S., Baldwin, T. T., \& Bommer, W. H. (2008). An examination of the structural, discriminant, nomological, and incremental predictive validity of the MSCEITC V2. 0. Intelligence, 36(4), 350-366. http://dx.doi.org/10.1016/j.intell.2007.07.002

Rostami, R., Shahmohamadi, K., Ghaedi, G., Besharat, M. A., Zardkhaneh, S. A., \& Nosratabadi, M. (2010). Relations among self-efficacy, emotional intelligence and perceived social support in university students. Ofogh-e-Danesh Journal, 16(3), 46-54.

Sakakibara, B. M., Miller, W. C., Orenczuk, S. G., \& Wolfe, D. L. (2009). A systematic review of depression and anxiety measures used with individuals with spinal cord injury. Spinal cord, 47(12), 841-851. http://dx.doi. org/10.1038/sc.2009.93

Salehi, S., Afghari, P., \& Moghadasi, M. H. (2012). Academic Achievement and Emotional Intelligence among Undergraduate Nursing Students of Isfahan University of Medical Sciences. Iranian Journal of Medical Education, 12(8).

Salovey, P., Mayer, J. D., Goldman, S. L., Turvey, C., \& Palfai, T. P. (1995). Emotional attention, clarity, and repair: Exploring emotional intelligence using the Trait Meta-Mood Scale. Emotion, Disclosure, and Health, 125, 154. http://dx.doi.org/10.1037/10182-006

Santrock, J. W., Woloshyn, V., Gallagher, T., Petta, T. D., \& Marini, Z. (2007). Educational Psychology. New York: McGraw-Hill.

Sarah, K. D., \& Neil, H. (2014). Ability versus trait emotional intelligence: Dual influences on adolescent psychological adaptation. J Individual Differences, 35(1), 54-62. http://dx.doi.org/10.1027/1614-0001/ a000127

Schutte, N. S., Malouff, J. M., Thorsteinsson, E. B., Bhullar, N., \& Rooke, S. E. (2007). A meta-analytic investigation of the relationship between emotional intelligence and health. Personality and Individual Differences, 42(6), 921-933. http://dx.doi.org/10.1016/j.paid.2006.09.003

Slaski, M., \& Cartwright, S. (2002). Health, performance and emotional intelligence: An exploratory study of retail managers. Stress and Health, 18(2), 63-68. http://dx.doi.org/10.1002/smi.926

Song, L. J., Huang, G.-H., Peng, K. Z., Law, K. S., Wong, C.-S., \& Chen, Z. J. (2010). The differential effects of 
general mental ability and emotional intelligence on academic performance and social interactions. Intelligence, 38(1), 137-143. http://dx.doi.org/10.1016/j.intell.2009.09.003

Spence, G., Oades, L. G., \& Caputi, P. (2004). Trait emotional intelligence and goal self-integration: Important predictors of emotional well-being? Personality and Individual Differences, 37(3), 449-461. http://dx.doi. org/10.1016/j.paid.2003.09.001

Stratton, T. D., Saunders, J. A., \& Elam, C. L. (2008). Changes in medical students' emotional intelligence: An exploratory study. Teaching and Learning in Medicine, 20(3), 279-284. http://dx.doi.org/10.1080/10401330 802199625

Surshejani, L. B. (2008). Relationship between emotional intelligence with mental health and educational performance of male and female students of Islamic Azad University of Behbehan Branch. Curriculum Planning, 5(19), 97-116.

Taghavi, M. H. (2002). Investigation of validity and reliability of general health questionnaire. Journal of Psychology, 5(4), 382-398.

Tamannaifar, M. R., Arfai, S. F., \& Mohammadabadi, F. S. (2010). Correlation between emotional intelligence, self-concept and self-esteem with academic achievement. Education Strategies in Medical Sciences, 3(3), 121-126.

Taylor, S. E., \& Sirois, F. M. (1995). Health psychology. New York: McGraw-Hill.

Williams, C., Daley, D., Burnside, E., \& Hammond-Rowley, S. (2010). Can trait Emotional Intelligence and objective measures of emotional ability predict psychopathology across the transition to secondary school? Personality and Individual Differences, 48(2), 161-165. http://dx.doi.org/10.1016/j.paid.2009.09.014

Yaghoobi, M., Navidian, A., Charkhat-gorgich, E. A. H., \& Salehiniya, H. (2015). Nurses' Perspectives of the Types and Causes of Medication Errors. Iran Journal of Nursing, 28(93), 1-10.

Yavarian, R., \& Ejaz, H. (2009). A study of emotional intelligence in medical students of Urmia University related to some individual characteristics and educational achievements. Journal of Urmia Nursing and Midwifery Faculty, 7(2), 114-119.

Zahiroddin, A. R., Dibajnia, P., \& Gheidar, Z. (2010). Evaluation of emotional intelligence among students of 4th grade in different medical majors in Shahid Beheshti University of Medical Sciences, 204-207.

\section{Copyrights}

Copyright for this article is retained by the author(s), with first publication rights granted to the journal.

This is an open-access article distributed under the terms and conditions of the Creative Commons Attribution license (http://creativecommons.org/licenses/by/3.0/). 